\title{
Biochar compared with activated granular carbon for landfill leachate treatment
}

\author{
Anna Kwarciak-Kozłowska ${ }^{1, *}$, Renata Włodarczyk $^{2}$, and Katarzyna Wystalska ${ }^{1}$ \\ ${ }^{1}$ Czestochowa University of Technology, Institute of Environmental Engineering, Faculty \\ of Infrastructure and Environment, ul. J. H. Dąbrowskiego 73, 42-200 Czestochowa, Poland \\ ${ }^{2}$ Czestochowa University of Technology, Institute of Advanced Energy Technologies, Faculty \\ of Infrastructure and Environment, ul. J. H. Dąbrowskiego 73, 42-200 Czestochowa, Poland
}

\begin{abstract}
The aim of the research was to compare the effectiveness of sorption of pollutants from landfill leachate on two granulated activated carbons (AG and BA-10) and biochar (BC). The sorption process of wastewater components on activated carbons was carried out under static conditions for 72 hours. The doses of adsorbents used varied from 2-8 $\mathrm{g} \cdot \mathrm{dm}^{-3}$. Results of removing of COD were estimated on the base of adsorption capacity and COD removal efficiency. After $72 \mathrm{~h}$ of the process at the highest doses $\left(8 \mathrm{~g} \cdot \mathrm{dm}^{-3}\right)$, the COD removal rate ranged from $40 \%$ (BA-10) to $60 \%$ (AG). In the case of biochar, the COD adsorption rate was $53 \%$ The state of sorption equilibrium takes a similar character for $\mathrm{BC}$ and $\mathrm{AG}$ and is determined after $4 \mathrm{~h}$. The degree of sorption of selected metals from landfill leachate using the analyzed range ranged from $84 \%$ to $96 \%$ depending on its type.
\end{abstract}

\section{Introduction}

At municipal landfills, the waste undergoes constant physicochemical and biological changes. In the results of rainwater infiltration through the waste deposit, organic and inorganic compounds are extracted. These compounds are often toxic and are a reason for the strong contamination of waters called landfill leachate [1-3]. Direct discharge of leachate into the natural environment could cause irreparable damage, especially to the surface and underground water systems [2]. Many factors influence the amount and composition of leachate, among others topography of the site, waste storage technology, type of waste and degree of fragmentation, hydrogeological and meteorological conditions or the age of the landfill [3-6]. It is estimated that from a densely compacted landfill with an annual rainfall of $0.7 \mathrm{~m}$ per $1 \mathrm{~m}^{2}$ of waste, within a day, 0.278 to $0.487 \mathrm{dm}^{3}$ of leachate is generated. For landfills with low density, this number is even three times higher [4]. The amount of leachate generated is also limited by the age of the landfill. On the young landfills, the production of leachate is slightly lower compared to the old ones (over 10 years of operation). This is related to the decreasing water retention capacity in waste and

\footnotetext{
*Corresponding author: akwarciak@is.pcz.czest.p1
} 
the increasing organic stabilization over time $[6,7]$. According to the landfill age, leachate can be classified into three types: young, middle-aged and stabilized (Table 1). The amount of pollution in one $\mathrm{m}^{3}$ of leachate from the landfill is equivalent to the amount of pollution found in 100 tonnes of municipal wastewater [1]. To date, over 200 organic substances have been identified as impurities in leachates, 35 of which belong to the so-called "Priority pollutants" [4]. Landfill leachate contains large amounts of organic and inorganic material, including a number of refractory organics such as aromatic compounds and humus; inorganic salts such as ammonia nitrogen, carbonate, and sulfate; and metal ions such as chromium, lead, and copper because the composition of the leachate is very complex and variable over time, there is no single universal method of purification [2-4].

Table 1. The effect of municipal landfill age on physicochemical characteristics of landfill leachate and efficiency of its treatment $[1,8,9]$.

\begin{tabular}{|c|c|c|c|}
\hline \multirow{2}{*}{$\begin{array}{c}\text { Characteristics of the landfill } \\
\text { leachate }\end{array}$} & \multicolumn{3}{|c|}{ Leachate type } \\
\cline { 2 - 4 } & $<\mathbf{5}$ years & 5-10 years & $>$ 10 years \\
\hline $\mathrm{pH}(-)$ & $<6.5$ & $6.5-8.0$ & $>8.0$ \\
$\mathrm{COD}\left(\mathrm{mg} / \mathrm{dm}^{3}\right)$ & $>10000$ & $<10000$ & $<3000$ \\
$\mathrm{BOD} / \mathrm{COD}(-)$ & $0.5-0.7$ & $0.3-0.5$ & $<0.13$ \\
$\mathrm{COD} / \mathrm{NH}_{4}+\mathrm{N}(-)$ & $5-10$ & $3-4$ & $<3$ \\
$\mathrm{NH}_{4}{ }^{+}-\mathrm{N}\left(\mathrm{mg} / \mathrm{dm}^{3}\right)$ & $500-1000$ & $800-2000$ & $1000-3000$ \\
& \multicolumn{3}{|c|}{ Process efficiency } \\
\hline Treatment methods & +++ & ++ & + \\
biological proces & + & ++ & ++ \\
chemical oxidation & + & ++ & + \\
chemical precipitation & + & ++ & +++ \\
adsorption & ++ & +++ & ++ \\
reverse osmosis & + & ++ & ++ \\
ozonation & + & ++ & ++ \\
ion exchange & &
\end{tabular}

+ low, ++ average, +++ beneficial

One of the decisive factors in the selection of leachate treatment technology is the economics of the process (investment and operating costs) and the effectiveness of a given technology in removing contaminants.

It is believed that the adsorption process is the most suitable technique for removing contaminants including metals from stabilized effluents [8-10]. Granular activated carbon $(\mathrm{GAC})$ is a safe product with a porous structure and extremely large specific surface area. Its properties depend on the properties of the raw material and the technology used. Currently, activated carbons are obtained in the process of thermal and/or chemical decomposition of substances containing significant amounts of fixed carbon. On an industrial scale as sorbents, hard coal, lignite, peat, half-coke or coke are used, but also the seeds of apricot and almond shell, the shell of the Italian coconut as well as nut shell [11-13]. Common GAC materials are comprised primarily of micropores $(>1 \mathrm{~nm})$ which are highly effective at adsorbing dissolved contaminants, but are easily blocked by suspended solids $[14,15]$. In recent years, research has been carried out to replace GAC with cheaper material. Biochar (BC) is often used directly with little post treatment modification and is generally less resource, energy, and capital intensive to manufacture compared to highly refined GAC [16]. It is assumed that the amount of energy needed to produce GAC from various sorbents ranges from 44 to $170 \mathrm{MJ} \cdot \mathrm{kg}^{-1}$, while for producing biochar it requires much smaller amounts in the range from 1.1 to $16 \mathrm{MJ} \cdot \mathrm{kg}^{-1}$ (i.e. up to 
$90 \%$ lower demand). The biochar changes the $\mathrm{pH}$ of soil, improves its fertility and yields crops [14-16]. Using spent BC material after wastewater/landfill leachate treatment as an agricultural amendment could further increase its life-cycle benefits. Table 2 depicted raw materials for the biochar's production, temperatures of pyrolysis process used during biochar production and impurities removed using a biocarbon adsorbent. The carbonization temperature affects the porosity of materials and the same on the adsorption capacity. As it appears from the literature, the process of removing contaminants using biochar proceed according to various mechanisms [19-27].

Table 2. The possibility of using BC for adsorption of inorganic compounds from liquid solutions.

\begin{tabular}{|c|c|c|c|c|}
\hline Raw material & $\begin{array}{c}\text { Process } \\
\text { temperature }\end{array}$ & Pollution & $\begin{array}{c}\text { Type and mechanism of } \\
\text { adsorption }\end{array}$ & Refs. \\
\hline manure & $200^{\circ} \mathrm{C}$ & $\mathrm{Pb}$ & precipitation of phosphates & {$[19]$} \\
\hline $\begin{array}{c}\text { straw from sugar } \\
\text { cane }\end{array}$ & $300^{\circ} \mathrm{C}$ & $\mathrm{Cr}$ & $\begin{array}{c}\text { reduction of } \mathrm{Cr}(\mathrm{VI}) \text { to } \\
\mathrm{Cr}(\mathrm{III})\end{array}$ & {$[20,21]$} \\
\hline oak wood & $450^{\circ} \mathrm{C}$ & & $\mathrm{sorption}$ & {$[22]$} \\
\hline wheat straw & $400^{\circ} \mathrm{C}$ & $\mathrm{Cu}$ & $\begin{array}{c}\text { adsorption by surface } \\
\text { complexation }\end{array}$ & {$[23]$} \\
\cline { 5 - 6 } & $800^{\circ} \mathrm{C}$ & & $\begin{array}{c}\text { sorption of humic acids at } \\
\text { pH } 6\end{array}$ & {$[24]$} \\
\hline nut shells & $700^{\circ} \mathrm{C}$ & $\mathrm{Hg}$ & $\begin{array}{c}\text { precipitation, complexation } \\
\text { and reduction }\end{array}$ & {$[25]$} \\
\hline soybean stalk & $250^{\circ} \mathrm{C}$ & $\mathrm{Ni}$ & $\begin{array}{c}\text { adsorption and partitioning } \\
\text { mechanisms }\end{array}$ & {$[26]$} \\
\hline \begin{tabular}{c} 
broiler litter manure \\
\cline { 4 - 5 }
\end{tabular} & $100^{\circ} \mathrm{C}$ & $\mathrm{Cd} / \mathrm{Pb}$ & $\begin{array}{c}\text { adsorption using aromatic } \\
\text { structure }\end{array}$ & {$[27]$} \\
\hline $\begin{array}{c}\text { wheat straw and } \\
\text { rapeseed }\end{array}$ & & & \multicolumn{2}{|c|}{} \\
\hline
\end{tabular}

To complement the performance of the adsorption process, the contact time (from several minutes to several hours), the temperature of the adsorption process (from $19^{\circ} \mathrm{C}$ to $46^{\circ} \mathrm{C}$ ), the $\mathrm{pH}$ of the solution from which the purification process was carried out should be taken into account. The adsorption effect is strongly influenced by the physical and chemical properties of sorbent-biochar (S-BC) [17]. The key parameters controlling its biochar as sorbent properties include pyrolysis temperatures, residence time in the reactor, heating speed and type of raw material [28-31]. The effectiveness of biochar in capturing contaminants depends on its specific surface area (SSA). SSA for biocarbon may range from approx. $0.77 \mathrm{~m}^{2} \cdot \mathrm{g}^{-1}$ to $1160 \mathrm{~m}^{2} \cdot \mathrm{g}^{-1}$ [18]. The high temperature of the pyrolysis process gives a product that is an effective adsorbent for the sorption of organic pollutants from the soil due to the increased surface area, microporosity and hydrophobicity. Biochars obtained at low temperatures are more suitable for removing inorganic/polar organic pollutants containing oxygen functional groups by electrostatic attraction. Sorption of pollutants from solutions is complex and the indication of the dominant process requires systematic analyzes taking into account the type of pollution and its origin, and biochar characteristics as a sorbent. This paper compares the efficiency of removing contaminants from leachate generated at an old landfill by using two types of granular activated carbons and biochar. 


\section{Materials and methods}

\subsection{Substrate}

The leachate was derived from the regional municipal waste landfill in Silesian Province (Poland). The landfill has been in operation since 1987, therefore it should be included in the group of "old landfills". This is evident from the values of leachate pollution indicators and the low BOD/COD ratio (0.059) indicating their low biodegradability (Table 3).

Table 3 Characteristics of landfill leachate used.

\begin{tabular}{|c|c|c|}
\hline Parameter & Unit & Value \\
\hline $\mathrm{pH}$ & - & $8.2-8.6$ \\
\hline $\mathrm{COD}$ & $\mathrm{mg} \cdot \mathrm{dm}^{-3}$ & $3098 \pm 20$ \\
\hline $\mathrm{BOD}$ & $\mathrm{mg} \cdot \mathrm{dm}^{-3}$ & $185 \pm 5$ \\
\hline $\mathrm{TOC}$ & $\mathrm{mg} \cdot \mathrm{dm}^{-3}$ & $550 \pm 10$ \\
\hline $\mathrm{Ni}$ & $\mathrm{mg} \cdot \mathrm{dm}^{-3}$ & 0.23 \\
\hline $\mathrm{Zn}$ & $\mathrm{mg} \cdot \mathrm{dm}^{-3}$ & 1.5 \\
\hline $\mathrm{Cu}$ & $\mathrm{mg} \cdot \mathrm{dm}^{-3}$ & 0.32 \\
\hline $\mathrm{Cd}$ & $\mathrm{mg} \cdot \mathrm{dm}^{-3}$ & 0.00303 \\
\hline $\mathrm{Pb}$ & $\mathrm{mg} \cdot \mathrm{dm}^{-3}$ & 0.01396 \\
\hline
\end{tabular}

The landfill is conducted by the prismatic method. The area designated for the landfill is 128.4 ha (plus a protection zone of 342 ha). As a result of infiltration of rainwater and technological sprinkling, waste solids are created there by approx. $60 \mathrm{~m}^{3} \cdot \mathrm{d}^{-1}$ of leachate. The purification process is carried out in a two-stage reverse osmosis process in a ROAD 9142 PALL-ROCHEM installation.

\subsection{Activated granular carbon}

The analysis was based on two granular activated carbons (GAC) with symbols: AG and BA-10. Both granular activated carbons were of Polish production (AG- Gryfskand Sp. z.o.o and BA-10 ELbar Katowice Sp. z.o.o.). Characterization of the activated carbons is presented in Table 4.

Table 4. Characteristic of studied activated carbons (PN-90/C-97555).

\begin{tabular}{|c|c|c|}
\hline Parameters & AG & BA-10 \\
\hline Specific surface, $\mathrm{m}^{2} \cdot \mathrm{g}^{-1}$ & $750-850$ & $\min .1000$ \\
\hline Bulk mass, $\mathrm{g} \cdot \mathrm{dm}^{-3}$ & $420-480$ & $490 \pm 30$ \\
\hline Typical grain size, $\mathrm{mm}$ & 1.5 & 3 \\
\hline Resistance mechanical, $\%$ & $92-96$ & 97 \\
\hline The ash content, $\%$ & $5-20$ & 5.94 \\
\hline
\end{tabular}

\subsection{Biochar}

Biochar (BC) was obtained in the autothermic process of carbonizing o the miscantus at $450^{\circ} \mathrm{C}$ during $60 \mathrm{~min}$. Technical analysis of biochar was made according to Polish Standard PN-G-04560:1998P (Table 5). The analysis of the content of carbon (C), hydrogen (H), nitrogen $(\mathrm{N})$ and sulphur $(\mathrm{S})$ was carried out in elemental analyzer (LECO). Heat of combustion was determined using IKA Basic C 2000 calorimeter using the isoperibolic method. Philips XL30/LaB6 scanning microscope was used for structural analysis of 
biochar. Porosity of biochar was determined using PoreMaster 33 mercury porosimeter with Quantachrome Instruments software. The open porosity of BC was estimated to $24.5 \%$ and specific surface area about $12.16 \mathrm{~m}^{2} \mathrm{~g}^{-1}$.

Table 5. Proximate and elemental ultimate analysis of biochar sample (dry): WT - total water, VM total volatile fractions, $\mathrm{Ad}_{d}-$ ash content $\left(575^{\circ} \mathrm{C}\right.$ - sample combustion temperature), $\mathrm{FC}$ - fixed carbon, $\mathrm{C}_{\mathrm{d}}$ - carbon content, $\mathrm{H}_{\mathrm{d}}$ - hydrogen content, $\mathrm{N}_{\mathrm{d}}$ - nitrogen content, $\mathrm{O}_{\mathrm{d}-\mathrm{oxygen}}$ content.

\begin{tabular}{|c|c|c|c|c|c|c|c|c|}
\hline $\mathbf{W T}, \boldsymbol{\%}$ & $\mathbf{V M}_{\mathbf{d}}, \boldsymbol{\%}$ & $\mathbf{A}_{\mathbf{d} 575}, \boldsymbol{\%}$ & $\mathbf{F C}, \mathbf{\%}$ & $\mathbf{C}_{\mathbf{d}},-$ & $\mathbf{H}_{\mathbf{d}},-$ & $\mathbf{N}_{\mathbf{d}},-$ & $\mathbf{S}_{\mathbf{d}},-$ & $\mathbf{O}_{\mathbf{d}},-$ \\
\hline 7.9 & 10.00 & 15.80 & 74.20 & 74.20 & 2.82 & 0.95 & 0.23 & 18.99 \\
\hline
\end{tabular}

\section{Research methodology}

Adsorption from landfill leachates was carried out under static conditions for jar tests of $250 \mathrm{~cm}^{3}$ with addition respectively: $0.5 \mathrm{~g}\left(\right.$ dose $\left.-2 \mathrm{~g} \cdot \mathrm{dm}^{-3}\right), 1 \mathrm{~g}\left(\right.$ dose $\left.-2 \mathrm{~g} \cdot \mathrm{dm}^{-3}\right)$, $1.5 \mathrm{~g}\left(\right.$ dose $\left.-6 \mathrm{~g} \cdot \mathrm{dm}^{-3}\right)$ and $2 \mathrm{~g}\left(\right.$ dose $\left.-8 \mathrm{~g} \cdot \mathrm{dm}^{-3}\right)$ adsorbents (GAC and BC). The contact time was $72 \mathrm{~h}$ with the mixing intensity was set at $200 \mathrm{rpm} \mathrm{min}^{-1}$. The effectiveness of the adsorption process at the assumed doses and the contact time, was examined based on the degree of removal of impurities designated as COD and concentrations of selected metals $(\mathrm{Ni}, \mathrm{Zn}, \mathrm{Cu}, \mathrm{Cd}$, and $\mathrm{Pb}$ ). Chemical Oxidation Demand (COD) was analyzed using colorimetric tests on Hach-DR 4000 photometer. Heavy metals were analysed inductively coupled plasma mass spectrometry (ICP-MS) analyser. The sorption capacity of the sorbents tested was calculated from the formula (1):

$$
q=\frac{\left(C_{0}-C_{t}\right) \cdot v}{m} T
$$

where $q$ is the adsorbent removal capacity of the given contaminant; $C_{0}$ is the initial and $C_{t}$ is the equilibrium concentration of the given contaminant $\left(\mathrm{mg} \cdot \mathrm{dm}^{-3}\right) ; v$ is the volume of solution $\left(\mathrm{dm}^{3}\right)$ and $m$ is the weight of the adsorbent $(\mathrm{g})$.

\section{Results and discussion}

\subsection{Analysis of the adsorbent dose effect on sorption capacity and on removal pollutions degree from landfill leachates}

In the first step, the time of sorption equilibrium was determined in static conditions on the adsorbents tested. The initial concentration of impurities designated as COD in the leachate from the landfill amounted to $3098 \mathrm{mg} \cdot \mathrm{dm}^{-3}$. It was found that irrespective of the adsorbent used, the sorption proceeded most intensely in the first 2 hours of the process. The time of the sorption equilibrium was similar to the biocarbon and active carbon $\mathrm{AG}$ and was established after 4 hours. The sorption equilibrium took place on the BA-10 granulated carbon $\left(6 \mathrm{~h}\right.$ at the dose of $\left.2 \mathrm{~g} \cdot \mathrm{dm}^{-3}\right)$. The discussed changes are presented in Fig. 1. The obtained test results in this stage show that extending the contact time above $10 \mathrm{~h}$ slightly affects the efficiency of the sorption process. In the case of biochar as well as activated carbon $\mathrm{AG}$, already for $0.5 \mathrm{~h}$ the sorption process at the dose of $2 \mathrm{~g} \cdot \mathrm{dm}^{-3}$ resulted in an average of $20 \%$ removal of impurities designated as COD. Increasing the dose of sorbents from $2 \mathrm{~g} \cdot \mathrm{dm}^{-3}$ to $4 \mathrm{~g} \cdot \mathrm{dm}^{-3}$ for all tested adsorbents resulted in an increase in the COD removal rate on $\mathrm{AG}, \mathrm{BA}-10$ and biochar, respectively by $9 \%, 12 \%$ and $6 \%$. After $72 \mathrm{~h}$ of 
the process at the highest doses $\left(8 \mathrm{~g} \cdot \mathrm{dm}^{-3}\right)$, the COD removal rate ranged from $40 \%$ (BA-10) to $60 \%$ (AG). In the case of biochar, the COD adsorption rate was $53 \%$ (Figure 2).

The research carried out showed that with increasing doses of adsorbents there was a decrease in the sorption capacity. It was noted that increasing the dose from $6 \mathrm{~g} \cdot \mathrm{dm}^{-3}$ to $8 \mathrm{~g} \cdot \mathrm{dm}^{-3}$ in the case of biochar and active carbon-AG did not affect its significant reduction anymore. The highest sorption capacity $\left(152.6 \mathrm{mg} \cdot \mathrm{g}^{-1}\right)$ was recorded for active carbon AG at the dose of $2 \mathrm{~g} \cdot \mathrm{dm}^{-3}$. Comparably at this dose, the sorption capacity for activated carbon BA-10 and biochar was $102.62 \mathrm{mg} \cdot \mathrm{g}^{-1}$ and $147.92 \mathrm{mg} \cdot \mathrm{g}^{-1}$, respectively (Figure 2).
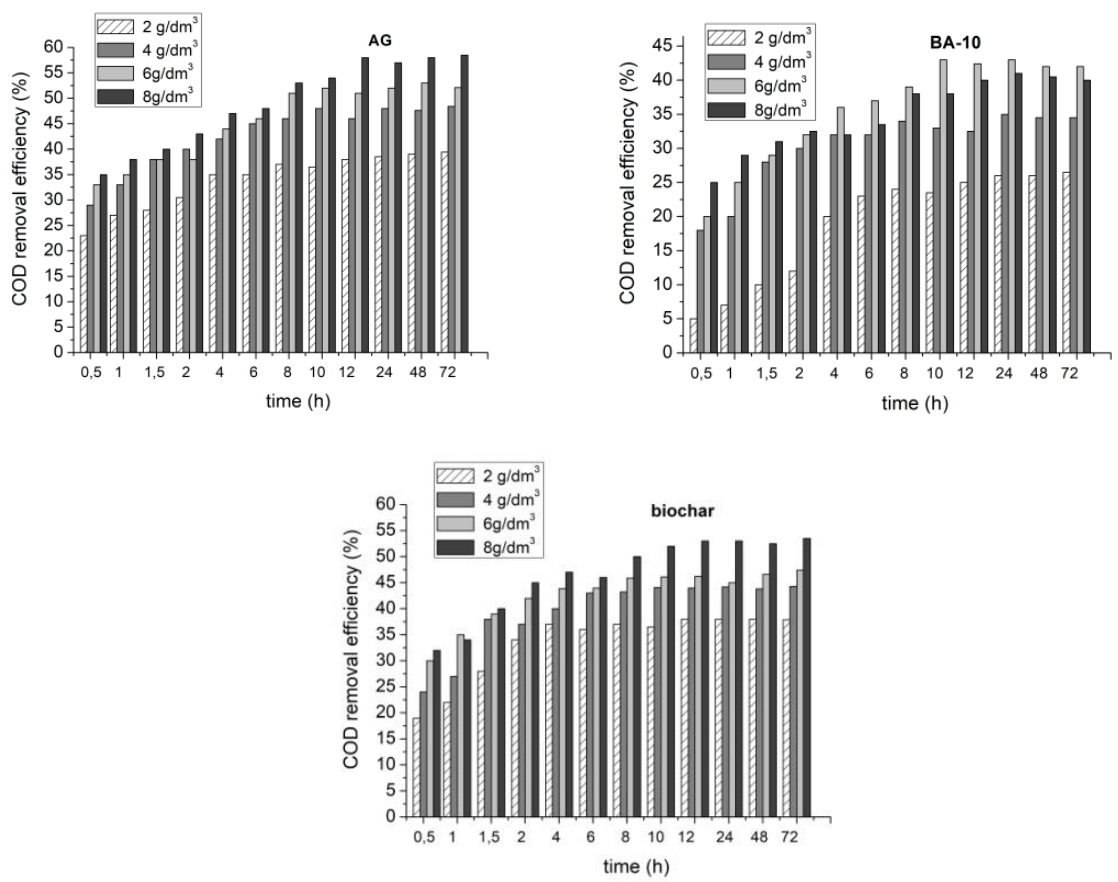

Fig. 1. Time determination of the sorption equilibrium for studied activated carbons and biochar.
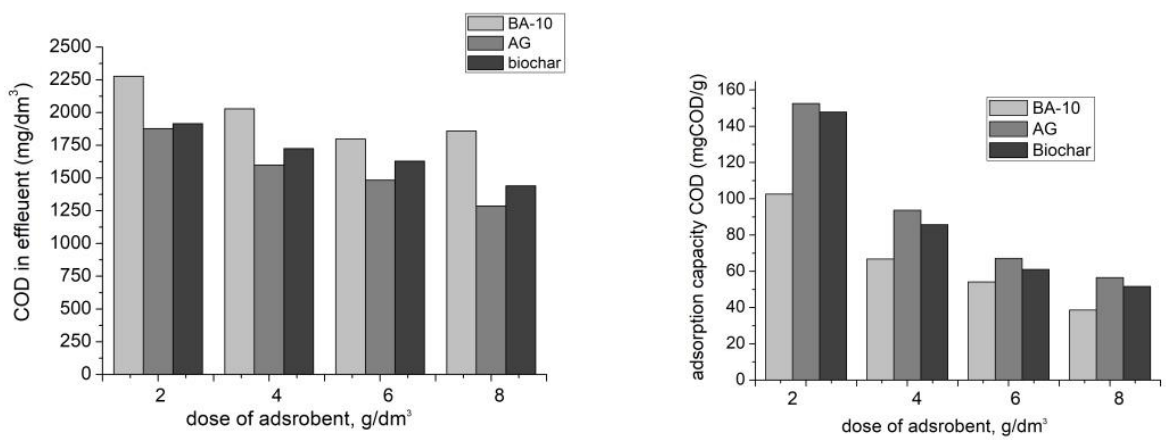

Fig. 2. The effect of adsorbent dose on sorption capacity and COD in effluent.

The Freundlich equation was used to describe the sorption isotherms. Using the logarithmic form of this equation, $\mathrm{KF}$ and $1 / \mathrm{n}$ constants were determined for the studied activated carbons and biochar, whose values are shown in Table 6. 
Table 6. The Freundlich isotherm constans from COD.

\begin{tabular}{|c|c|c|c|}
\hline Carbons & $\mathbf{K}_{\mathbf{F}}, \mathbf{m g} / \mathbf{g}$ & $\mathbf{1 / n}$ & $\mathbf{R}^{\mathbf{2}}$ \\
\hline AG & 6.94 & 0.6098 & 0.931 \\
\hline BA-10 & 10.30 & 0.6502 & 0.928 \\
\hline Biochar & 5.80 & 0.5182 & 0.879 \\
\hline
\end{tabular}

Numerous studies confirm that the sorption of pollutants on biochars can proceed with similar effectiveness as on granular activated carbons [11, 13-15, 32]. The degree of removal of COD may vary from $45 \%$ to $95 \%$ and depends on the type of biocarbon used, its activation or absence as well as on the concentration and type of pollutants in the wastewater. In the future, it is planned to carry out a modification of biochar (thermal or chemical) in order to improve the efficiency of sorption of contaminants on its surface. Huggins and el. 2016 [15] have observed even higher COD (raw wastewater $1243 \mathrm{mg} \cdot \mathrm{dm}^{-3}$ ) removal rate by over $10 \%$ on the biochar compared to granular activated carbon. The biochar used in their studies was characterized by a $30 \%$ higher sorption capacity (70 mg COD g${ }^{-1}$ ) compared to GAC (49.3 $\mathrm{mg} \mathrm{COD} \mathrm{g}^{-1}$ ). Unlike the authors of the work, Huggins and el. 2016 [15] determined the dependence of sorption capacity on the equilibrium concentration and not on the amount of adsorbents used.

After analyzing the obtained test results, it is stated that in the case of activated carbon $\mathrm{AG}$ as well as biochar, it is most advantageous to conduct the sorption process of contaminants designated as COD from landfill leachate at their dose level of $6 \mathrm{~g} \cdot \mathrm{dm}^{-3}$. Therefore, in the above attempts of treated landfill leachates changes in concentrations of selected metals were analyzed. The degree of metal sorption has the adsorbents used and was similar and ranged from $84 \%$ to $96 \%$ depending on its type (Table 7 ).

Table 7. Intial and final concentration for AG, BA-10 and biochar.

\begin{tabular}{|c|c|c|c|c|}
\hline \multirow{2}{*}{ Metal } & \multirow{2}{*}{$\begin{array}{c}\text { Intial metal } \\
\text { concentration }\end{array}$} & \multicolumn{3}{|c|}{ Final metal concentration } \\
\cline { 3 - 5 } & 0.23 & 0.0253 & 0.0207 & Biochar \\
\hline $\mathrm{Ni}$ & 1.5 & 0.033 & 0.03 & 0.0368 \\
\hline $\mathrm{Zn}$ & 0.32 & 0.0576 & 0.0672 & 0.064 \\
\hline $\mathrm{Cu}$ & 0.00303 & 0.00048 & 0.00033 & 0.00039 \\
\hline $\mathrm{Cd}$ & 0.01396 & 0.0011 & 0.00055 & 0.000695 \\
\hline $\mathrm{Pb}$ & & &
\end{tabular}

As results from the research and reports, biochar is an attractive adsorbent of organic pollutants and heavy metals [19-27]. The use of porous biochar in the aeration chamber during the biological treatment of leachate as a carrier of activated sludge flocs will allow simultaneous biodegradation and adsorption of pollutants.

\section{Conclusions}

In the work, the adsorption of pollutants from landfill leachates was analyzed in static conditions. The sorption properties of two granular activated carbons (GAC) with symbols: $\mathrm{AG}$ and BA-10 with biochar made from miscantus in pyrolysis process were compared. On the basis of the conducted research, the following statements and conclusions were formulated:

- the state of sorption equilibrium takes a similar character for $\mathrm{BC}$ and $\mathrm{AG}$ and is determined after $4 \mathrm{~h}$. The sorption equilibrium was observed on BA-10 granulated coal (after $6 \mathrm{~h}$ at the dose of $2 \mathrm{~g} \cdot \mathrm{dm}^{-3}$ ), 
- 30 min of conducting sorption process from sewage effluents with the inclusion of BC and $\mathrm{AC}$ gives a $20 \%$ effect of removing impurities designated as COD, and extending the duration of the process to 72 hours allows the removal of COD up to $60 \%$,

- the sorption capacity AG at a dose of $2 \mathrm{~g} \cdot \mathrm{dm}^{-3}$ was established at $152.6 \mathrm{mg} \cdot \mathrm{g}^{-1}$, comparable with this dose, the sorption capacity for activated carbon BA-10 and biochar was $102.62 \mathrm{mg} \cdot \mathrm{g}^{-1}$ and $147.92 \mathrm{mg} \cdot \mathrm{g}^{-1}$,

- the degree of sorption of selected metals from landfill leachate using the analyzed range ranged from $84 \%$ to $96 \%$ depending on its type.

The study has been funded by BS/PB-401-301/11.

\section{References}

1. K. Wang, L. Li, F. Tan, D. Wu, Hindawi Archea, 2018 (2018)

2. F. N. Ahmed, C. Q. Lan, Desalination 287, 41-54 (2012)

3. G. Li, W. Wang, Q. Du, Journal of Applied Polymer Science 116, 2343-2347 (2010)

4. B. Zadroga, K. Olańczuk-Neyman, Wydawnictwo Politechniki Gdańskiej (2001)

5. J. Bohdziewicz, E. Neczaj, A. Kwarciak, Desalination 221, 559-565 (2008)

6. S. M. Joshi, P. R. Gogate, Separation and Purification Technology 211, 10-18 (2019)

7. L. Jurczyk, J. Koc-Jurczyk, M. Balawejder, Journal of Ecological Engineering 20, 204-213 (2019)

8. J. Bohdziewicz, A. Kwarciak, Desalination 222, 128-134 (2008)

9. A. Kwarciak-Kozłowska, L. Sławik-Dembiczak, Inżynieria i Ochrona Środowiska 19, 561-575 (2016)

10. A. Kwarciak-Kozłowska, Journal of Ecological Engineering 19, 186-193 (2018)

11. X. Tan, Y. Liu, G. Zeng, X. Wang, X. Hu, Y. Gu, Z. Yang, Chemosphere 125, 70-85 (2015)

12. L. Dąbek, Annual Set The Environment Protection 17, 616-645 (2015)

13. D. Mohan, A. Sarswat, Y. S. Ok, Ch. U. Pittman Jr., Bioresource Technology 160, 191-202 (2014)

14. S. S. Dalahmeh, SLU Report, 090 (2016)

15. T. Huggins, A. Haeger, J. C. Biffinger, Z. J. Ren, Water Research 94, 225-232 (2016)

16. fingerlakesbiochar.com

17. B. Wang, B. Gao, J. Fang, Critical Reviews In Environmental Science And Technology 0, 1-50 (2017)

18. A. D. Lewis, E. G. Fletcher, T. H. Fletcher, Pyrolysis and $\mathrm{CO}_{2}$ Gasification Rates of Biomass at High Heating Rate Conditions (Western States Section of the Combustion Institute and Hosted by the University of Utah May 19-22, 2013)

19. A. B. Duwiejuah, S. J. Cobbina, N. Bakobie, International Journal of Environmental Bioremediation \& Biodegradation 5, 27-40 (2017)

20. R. A. Wuana, F. E. Okieimen, Communicat. Soil Sci. Plant Anal. 42, 111-122 (2011)

21. M. Uchimiya, I. M. Lima, K. T. Klasson, S. Chang, L. H. Wartelle, J. E. Rodgers, J. Agric. and Food Chem. 58, 5538-5544 (2010) 
22. A. Dowie, A. Crosky, P. Muroe, Physical properties of biochar (in BC for environmental management, J. Lehmann and S. Joseph, Eds., 47-82, Earthscan, London, UK, 2009)

23. R. Qiu, H. Lu, W. Zhang, Y. Yang, X. Huang, S. Wang, Wat. Res. 46, 854-862 (2012)

24. S. Babel, T. A. Kurniawan, Chemosph. 54, 7, 951-967 (2004)

25. Z. Song, F. Lian, Z. Yu, L. Zhu, B. Xing, W. Qiu, Chemical Engineering Journal, 242, 36-42 (2014)

26. D. Mohan, S. Rajput, V. K. Singh, P. H. Steele, C. U. Pittman Jr., Journal of Hazardous Materials 188, 319-333 (2011)

27. X. Tong, J. Li, J. Yuan, R. Xu, Chemical Engineering Journal 172, 828-834 (2011)

28. S. De Gisi, G. Lofrano, M. Grassi, M. Notarnicola, Sustainable Materials and Technologies 9, 10-40 (2016)

29. H. Kong, J. He, Y. Gao, H. Wu, X. Zhu, J. Agric. Food Chem. 59, 12116-12123 (2011)

30. M. Uchimiya, I. M. Lima, K. T. Klasson, S. Chang, L. H. Wartelle, J. E. Rodgers, J. Agric. and Food Chem. 58, 5538-5544 (2010)

31. K. Štefušová, M. Lovás, A. Zubrik, M. Matik, M. Václavíková, Nova Biotechnologica Et Chimica 11, 139-146 (2012)

32. S. B. Chavda, M. J. Pandya, IJIRT 1, 101472, 1-5 (2014) 